ЦИФРОВІЗАЦІЯ ТА ІІЇ ВПЛИВ НА ОСВІТНІЙ ПРОСТІР У КОНТЕКСТІ ФОРМУВАННЯ КЛЮЧОВИХ КОМПЕТЕНТНОСТЕЙ

\title{
DIGITALIZATION AND ITS IMPACT ON THE EDUCATIONAL SPACE IN THE CONTEXT OF THE FORMATION OF KEY COMPETENCIES
}

УДК 378. 046.4

DOI https://doi.org/10.32843/2663-

$6085 / 2020 / 22-2.20$

\section{Кучерак I.B.,}

канд. пед. наук,

доцент кафедри професійної освіти

та нноваційних технологій

Інституту післядипломної освіти

та довузівської підготовки

Прикарпатського національного

університету імені Василя Стефаника

\begin{abstract}
у статті проаналізовано можливості використання цисррових технологій для формування ключових компетентностей. Систематизовано нормативно-правові документи, які характеризують доцільність впровадження діджиталізації в освіті. Розкрито зміст цисрровізації. Обгрунтовано необхідність цифррової трансформації системи освіти, побудови навчального процесу на кросплаторормовому форматі з упровадженням новітніх методик. Представлено й узагальнено результати опитування учителів початкової школи. Актуалізовано необхідність пошуку більш есрективних шляхів впровадження цисрровізації як комплексу інструментів, що оптимізують навчання, забезпечують персоналізацію й автоматизацію рутинних освітніх процесів. Дослідження дозволило сфрормулювати висновки про те, що вчителі розуміють необхідність цифрровізації освітнього простору, однак на практиці інновації використовують лише частково. Така ситуація спричинена відсутністю навчально-методичного забезпечення та наукової літератури. Опитування підтвердило фррагментарний характер впровадження діджиталізації.

Визначено основні напрями подальших наукових розробок, враховуючи тематику дослідження.

Ключові слова: цисрровізація, цисррові технології, освітне середовище, компетентність, учитель початкової школи.
\end{abstract}

The article analyzes the possibilities of using digital technologies to form key competencies. Systematized legal documents that characterize the feasibility of implementing digitalization in education. The content of digitalization is revealed. The necessity of digital transformation of the education system, building the educational process on a cross-platform format for the introduction of new techniques is justified. The results of the survey of primary school teachers are presented and summarized. The need to find more effective ways to implement digitalization not as a separate tool, but as a set of tools that optimize learning, provide personalization and automation of routine educational processes, is actualized. The study allowed us to formulate conclusions that teachers understand the need to digitalize the educational space, but in practice, innovations are only partially used. This situation is caused by the lack of educational and methodological support and scientific literature. The survey confirmed the fragmentary nature of digitalization implementation.

The main directions of further scientific developments are defined, taking into account the research topic.

Key words: digitalization, digital technologies, educational environment, competence, primary school teacher.
Постановка проблеми у загальному вигляді. Якісні зміни у вітчизняному освітньому просторі неможливі без глобальних трансформацій і цифровізації - впровадження сучасних цисррових технологій. Проте часто цифровізацію сприймають лише в ракурсі модного освітнього тренду, задовольняючись її поверхневим упровадженням, використанням із метою оцінювання знань учнів або візуалізації навчального матеріалу функціоналу хмарних технологій, цифррової обробки даних, програмного забезпечення. Однак чи можливі стратегічні зміни та якісні трансорормаційні процеси за такого вузького вирішення проблеми?

Виділення не вирішених раніше частин загальної проблеми. Сучасна епоха кіберсоціалізації суспільства актуалізує потребу особистості діяти ефективно, виконуючи різні соціальні фуннції в умовах кіберпростору, як самостійно, так і як суб'єкта (у складі команди). 3 огляду на означене та $з$ метою досягнення якісних перетворень постає необхідність тотальної цисрровізації, цисррової транссормації, що передбачатиме впровадження нової освітньої парадигми, побудови навчального процесу на кросплаторормовому фрорматі з упровадженням новітніх методик, метою якої $є$ спря- мованість на результат - фрормування ключових компетентностей.

Аналіз останніх досліджень і публікацій. На необхідності цисровізації освітньої сфери акцентовано в низці нормативно-правових документів. Зокрема, у Законі України «Про освіту» (2017) поміж ключових компетентностей визначено інформаційно-комунікаційну.

У проекті Концепції Цифррової адженди України - 2020 зазначено, що цифровізація має стати об'єктом фрокусного та комплексного державного управління. Про потребу у розвитку «електронного навчання і формування цифрової компетентності учасників освітнього процесу» зазначається й у наказі Міністерства освіти і науки України «Про затвердження Положення про Національну освітню електронну платсрорму» (2018) [3].

Різні аспекти впровадження цифровізації в освітній простір стали предметом дослідження зарубіжних (К. Бассет (С. Bassett), К. Гере (C. Gere), Г. Грибер (G. Creeber), М. Деузе (M. Deuze), Г. Крибер і P. Мартін (G. Greeber \& R. Martin), Л. Манович (L. Vanovich), Дж. Стоммел (J. Stommel), М. Хенд (M. Hand) і вітчизняних (В. Биков, Д. Галкін, М. Жалдак, М. Лещенко, П. Матюшко, О. Овчарук, 
В. Ребрина, О. Стрижак, М. Шишкіна, А. Яцишин) науковців.

Однак, незважаючи на проявлений науковою спільнотою інтерес, питання впровадження цисрровізації в сучасний освітній простір задля реалізації ключових компетентностей, зокрема майбутніх учителів початкової школи, все ще потребують більш детального вивчення. Означене визначило вибір теми дослідження.

Мета статті - систематизувати нормативноправові документи, які характеризують доцільність впровадження діджиталізації в освіті, проаналізувати можливості використання в освітньому процесі цифрових технологій, переваги цифрової трансорормації системи освіти, представити результати опитування учителів початкової школи.

Виклад основного матеріалу. Цифрові технології полегшують життя, оптимізуючи рутинні процеси, нівелюючи кордони в освітньому просторі, що виходить за межі своєї країни та континенту. 3 іншого боку, таке тотальне впровадження підвищує вимоги до рівня фрахової підготовки працівників, посилюючи конкуренцію на ринку праці. Адже постає потреба у висококвалісрікованому фрахівцеві, котрий володіє певними компетентностями, зможе ефрективно, появляючи активність, відповідальність, наполегливість і креативність, вирішувати завдання самостійно та (або) у складі команди.

Цифровізація - відображення сучасної парадигми розвитку суспільства, коли конкурентоспроможність та ефективність постають як життєво необхідні якості. «Цифрровізація сприяє спрощенню освітнього процесу, роблячи його більш гнучким, пристосованим до реалій сучасного дня, що забезпечує фрормування конкурентоспроможних професіоналів» [2, с. 188].

Протягом XX ст. модернізація освіти була зосереджена переважно на оновленні ії змісту. Але у XXI ст. цього уже недостатньо, адже посилюється необхідність удосконалення організаційних фрорм, методів, засобів навчання, створення дієвого цифрового освітнього простору завдяки цифровізації освіти.

Цифрровізація (діджиталізація) освітнього процесу спричинена потребою у широкому впровадженні інноваційних технологій, появою нових вимог до фрахівців, зокрема до фрормування ключових компетентностей, і нового цифрового покоління (з особливими соціально-психологічними характеристиками).

Завдяки ретельно організованому цифровому середовищу освіта стає більш доступною і комфортною, що вкрай важливо за умов мінімальних затрат - часових, фрінансових, людських ресурсів. А для сучасної молоді - це ще й звична площина, в якій є всі умови розвитку, своєрідний ліфтинг для реалізації індивідуальності кожної людини та комфрортного упровадження інновацій.
Важливі не лише самі інсормаційні технології, a і їх правильний підбір, поєднання й управління ними з метою налагодження ефективної роботи.

Переваги цифррової трансформації освіти очевидні. Зокрема, це забезпечення сприятливих умов для:

- розвитку умінь навчатися самостійно, виокремлювати найбільш цінний матеріал для саморозвитку;

- формування мобільності особистості, умінь швидко адаптуватися до умов, що змінюються непередбачувано і стрімко;

- посилення мотивації до самоосвіти та саморозвитку;

- охоплення різноманітної аудиторії (контент стає персоналізованим), забезпечення співпраці та інтегративності;

- побудови індивідуальної освітньої траєкторії;

- навчання у найбільш зручних умовах - комфортному темпі, але $з$ оптимальним використанням часу, виокремленого для виконання певних завдань.

$\mathrm{Ta}$, найголовніше, діджиталізація забезпечує перехід від «освіти для всіх до освіти для кожного». Таким чином, розбудовується сучасний освітній простір, у якому $є$ всі умови для оволодіння базовими (надпрофесійними) компетенціями.

Цифровізація передбачає принципово новий формат освітнього середовища, в основі якого цифррові технології, що забезпечують зручні та доступні сервіси і платформи для підвищення конкурентоспроможності, більш ефективної взаємодії усіх учасників навчального процесу, підвищення його прозорості, підвищення ролі інтелектуальної власності, розвитку цифрових навичок.

У Цифрровій адженді України говориться про те, що цифровізація $є$ механізмом для економічного зростання завдяки приросту ефективності та збільшенню продуктивності від використання цифррових технологій [5]. Аналогічне стосується і сорери освіти.

Однак цифровізація жодним чином не повинна сприйматися виключно як самоціль. Вона - лише інструмент, що створює переваги та надає до них простий доступ, це зміна парадигми того, як саме ми міркуємо, які інструменти обираємо для дій, яким стратегіям надаємо перевагу у спілкуванні один з одним та із зовнішнім середовищем.

Тотальна діджиталізіція освіти передбачає цілу низку дій. Насамперед це розбудова сучасної інфрраструктури, модернізація законодавчої площини, а також підготовка кваліфікованих фрахівців, котрі володіють цифровою компетентністю. Така грамотність $€$ пріоритетною, адже дозволяє набувати компетенцій в інших сорерах більш ефективно, витрачаючи менше зусиль і часу.

Ще у 2016 р. у представленому ЄС оновленому фрреймворку Digital Competence (DigComp 2.0) 
визначено 5 блоків компетенцій. Поміж ними інорормаційна грамотність, вміння оцінювати, використовувати й управляти даними, взаємодіяти завдяки використанню цисррових технологій, створювати, змінювати і покращувати цифровий етикет, вирішувати проблеми із комп'ютерною технікою та програмним забезпеченням, а також визначати потребу в отриманні нових цисрових навичок [5]. Щороку потреба в оволодінні зазначеними компетенціями лише посилюється.

3 іншого боку, такі технології не виключають роботи учителя початкової школи, адже не є покликаними його замінити. Їхній потенціал спрямований на інше - доповнення, удосконалення, урізноманітнення, оптимізацію. Проте фрункції педагога кардинально змінюються. Уміння працювати із великою кількістю інформації, вирішувати проблемні ситуації, відстоювати власну позицію та бути готовим до конструктивних діалогів - те, що у пріоритеті. Для досягнення цифровізації системи освіти такі зміни не повинні обмежуватися аудиторією чи класом (використанням цифрової техніки), вони мають пронизувати усі сорери та напрями діяльності закладу освіти, забезпечуючи перехід навчання на принципово новий, більш високий рівень.

Цифрові технології відрізняються дидактичним потенціалом, що забезпечує свободу пошуку інфрормації, іï персоналізацію (орієнтацію на потреби учнів - різний рівень складності, темп, подача матеріалу), інтерактивність, мультимедійність, субкультурність. Такі інновації створюють ситуацію комфорту.

Незважаючи на всі переваги, якими вирізняється цисрровізація, її впровадження все ще має фррагментарний характер. Це підтвердили результати здійсненого нами дослідження. Респонденти - учителі початкової школи закладів загальної середньої освіти Івано-Франківської міської ради. Загальна кількість педагогів, котрі взяли участь в анонімному опитуванні, - 74. На питання, чи використовуєте ви інноваційні технології у своїй роботі, отримано 10 відповідей «ні» (13,5\%) і 64 відповіді - «так» (86,5\%). Складнощі виникли при формулюванні відповіді на питання, які саме інновації використовуються. Зокрема, 22 респонденти $(29,7 \%)$ не змогли відповісти на це питання.

Однак надалі в індивідуальних розмовах виявилося, що всі опитувані використовують інновації у своїй роботі, а в анкетуванні такі дані не вказали лише тому, що мали сумніви стосовно класифрікації (чи належить технологія до цисрової) або не володіли науковою термінологією.

Усі 74 респонденти (100\%) вказали на потребу у вдосконаленні рівня оволодіння цифровими технологіями, на брак необхідної наукової та методичної літератури та підготовки - підвищення рівня кваліфікації у вигляді тренінгів.
Означене дослідження дозволило сформулювати такі висновки. Учителі розуміють необхідність цифрровізації освітнього простору, однак на практиці інновації використовують лише частково. Така ситуація спричинена відсутністю навчальнометодичного забезпечення та наукової літератури. Опитування підтвердило фррагментарний характер впровадження діджиталізації.

Висновки. Сьогодні цифрровізація постає як ключовий фрактор удосконалення системи освіти. Окрім безпосереднього впливу на ефективність навчального процесу, діджиталізація надає ланцюг непрямих переваг, зокрема оптимальне використання часу задля більш ефективного фрормування ключових компетентностей.

Завдяки циорровізації освітній процес стає більш персоналізованим, доступним і гнучким. Це, у свою чергу, забезпечує комфортні умови для самонавчання, ефективного розвитку та кар'єрного зростання.

Означене дослідження підтвердило актуальність цифровізації освітнього простору в контексті формування ключових компетентностей і довело необхідність подальшої розробки проблеми, зокрема пошуку більш ефективних шляхів впровадження цифрровізації як комплексу інструментів, що оптимізують навчання, забезпечують персоналізацію й автоматизацію рутинних освітніх процесів.

\section{БІБЛІОГРАФІЧНИЙ СПИСОК:}

1. Е-платформа Нова українська школа. URL: http://nus.inf.ua/.

2. Карплюк С.О. Особливості цисрровізації освітнього процесу у вищій школі. Інфрормаційно-цифрровий освітній простір України: трансформаційні процеси і перспективи розвитку. Матеріали методологічного семінару НАПН України. 4 квітня 2019 р. I за ред. В. Кременя, О. Ляшенка ; укл. А.В. Яцишин, О.М. Соколюк. Київ, 2019. С. 188-197.

3. Про затвердження Положення про Національну освітню електронну платформу : наказ № 523 від 22 травня 2018 р. / Міністерство освіти і науки України. URL: https://ips.ligazakon.net/document/ RE32154?an=103.

4. Smart-освіта: ресурси та перспективи : матеріали III Міжнар. наук.-метод. конф. (Київ, 7 грудня 2018 р.) : тези доповідей. Київ : Київ. нац. торг.-екон. ун-т. 2018. 252 с.

5. Цисррова адженда України - 2020 («Цисрровий порядок денний - 2020»). Концептуальні засади. Першочергові сфрери, ініціативи, проекти «цифровізації» України до 2020 р. 2016. Грудень. 90 с. URL: https://www.rada.gov.ua/uploads/documents/40009.pdf.

6. Цифрова компетентність сучасного вчителя нової української школи: зб. тез доповідей учасників всеукр. наук.-практ. семінару (Київ, 28 лютого 2018 р.) / за заг. ред. О. Коневщинської, О. Овчарук. Київ, Інститут інфрормаційних технологій і засобів навчання НАПН України, 2018. 61 с.

7. Цифрові технології в освітньому процесі закладів освіти : збірник матеріалів VII Всеукраїн- 
ської інтерактивної науково-практичної конференції / упоряд. Н.А. Басараба. Рівне, РОІППО, 2019. 126 с.

8. Фамілярська Л.Л. Модель навчального середовища у післядипломній педагогічній освіті. URL: http://www.confcontact.com/2016-specproekt/ familyarskaya.html.

9. A Digital Agenda for Europe: Communication from the commission to the European Parliament, the Council, the European Economic and Social
Committee and the Committee of the Regions, Brussels. 2010. URL: http://eur-lex.europa.eu/ legalcontent/EN/TXT/HTML/?uri=CELEX:52010DC02 $45 \mathrm{R}(01) \&$ from $=E N$.

10.Buzzard C., Crittenden V.L., Crittenden W.F. \& McCarty P. The Use of Digital Technologies in the Classroom:ATeaching and Learning Perspective. Journal of Marketing Education. 2011. № 33 (2). P. 131-139. URL: https://doi.org/10.1177/0273475311410845. 